\title{
Formation of Eskişehir Province Flood Maps with Using of Geographical Information Systems
}

\author{
Yıldırım Bayazit'¹, Recep Bakiş², Cengiz Koç3 ${ }^{3}$ Turgut Kaya ${ }^{4}$, Nedim Özdemir ${ }^{5}$ \\ ${ }^{1}$ Department of Civil Engineering, Bilecik Şeyh Edebali University, Bilecik, Turkey \\ ${ }^{2}$ Department of Civil Engineering, Eskisehir Technical University, Eskişehir, Turkey \\ ${ }^{3}$ Department of City and Regional Planning, Mugla Sitkı Kocman University, Muğla, Turkey \\ ${ }^{4}$ Department of Construction, Vocational School, Batman University, Batman, Turkey \\ ${ }^{5}$ Department of Basic Sciences, Faculty of Fisheries, Mugla Sitkı Kocman University, Mugla, Turkey \\ Email: yildirim.bayazit@bilecik.edu.tr, rbakis@eskisehir.edu.tr, cengizko9@gmail.com.tr, turgut.kaya@batman.edu.tr, \\ ata.dadaoz@gmail.com
}

How to cite this paper: Bayazit, Y., Bakiş, R., Koç, C., Kaya, T., \& Özdemir, N. (2019). Formation of Eskişehir Province Flood Maps with Using of Geographical Information Systems. Journal of Geoscience and Environment Protection, 7, 151-159. https://doi.org/10.4236/gep.2019.711011

Received: August 25, 2019

Accepted: November 23, 2019

Published: November 26, 2019

Copyright (๑) 2019 by author(s) and Scientific Research Publishing Inc. This work is licensed under the Creative Commons Attribution International License (CC BY 4.0).

http://creativecommons.org/licenses/by/4.0/

\begin{abstract}
In this study, it is aimed to develop the flood risk analysis of Porsuk River, which is responsible for naming of the Porsuk Basin sub basin of Sakarya Basin, by utilizing the methods of Remote Sensing (RS) and Geographical Information Systems (GIS). In addition, flood elevation effects of Porsuk River in Eskişehir city and the regions around were investigated. Necessary data for study were obtained from Eskişehir 3. Regional Directorate of State Hydraulic Works archives. For analyses, the cross section of Porsuk River was defined in the Hydrologic Engineering Centers River Analysis System (HEC-RAS) software. Subsequently, recurring periods of 50, 100 and 1000 years discharge of Porsuk River which is calculated as $51.83 \mathrm{~m}^{3} / \mathrm{s}, 60.15 \mathrm{~m}^{3} / \mathrm{s}$ and $86.66 \mathrm{~m}^{3} / \mathrm{s}$ respectively were inputted in the software to obtain analysis results. Obtained results from the present study and topographic data were compared and interpreted. As a result, elevation of flood and its risks for urban regions were studied and presented.
\end{abstract}

\section{Keywords}

GIS, HEC-RAS, Flood, Porsuk River, Eskişehir

\section{Introduction}

Floods are defined as the occurrence of a natural disaster by a river overflowing 
from its bed for various reasons, causing damage to the surrounding lands, settlements, infrastructure facilities and living beings and creating a flow size to the extent that it interrupts normal socio-economic activity in the impact zone (Uşkay \& Aksu, 2002). Floods may occur naturally or may be caused by irregular urbanization, closure of river beds, destruction of vegetation and insufficient precautions. Determining the areas that may be exposed to natural or man-made floods and determining the measures to be taken against floods is one of the important problems that remain a contemporary problem in terms of engineering.

Within the scope of this study, flood modeling studies have been carried out in the regions where Porsuk Stream in Porsuk Basin passes through the center of Eskişehir. For this purpose, numerical elevation model (NEM) and HEC-RAS (HEC, 2010) based hydraulic models of the basin area were established in a geographical information systems (GIS) environment. In addition, 50, 100 and 1000 year recurring flood flow values for Porsuk Creek were obtained by analyzing the flow data obtained from the 3rd Regional Directorate of DSI. Then, flood scenarios were developed for Eskişehir province and then the regions with risk of flood were determined using these flow rates obtained for these different recurring periods.

\section{Materials and Method}

Since floods are one of the natural disasters that cause great loss of life and property in many parts of the world, the areas where floods may be at risk should be determined. In this context, it is necessary to establish the infrastructure in order to determine the areas where the surface profiles formed by the HEC on the 3D terrain models to be established through GIS and to take measures (HEC, 2009, 2010; Singh, 1996).

GIS is a system that performs the functions of obtaining, storing, storing, processing and presenting the graphical (spatial or geographical) and non-graphical (spatial) data obtained by location-based observations in a unified manner. GIS has been used for many years to determine water quality, to take flood measures and to solve water related problems such as providing water supply. In particular, hydrologists need data such as water resources, precipitation, drainage, flow movement and water quality for the GIS solutions to be prepared in order to solve these problems (Durdu, 2003; Kılıçeri, 2000; Özcan et al., 2009; Özcan, 2008; Ozdemir, 2007).

There are many studies in the literature on flood risk analysis. In order to be given some of these studies, Silva et al. (2014) showed the potential of using HEC-RAS and GIS software for high-resolution imaging of the flood areas. In this study, HEC-RAS model was simulated in the city of Rios dos Cedros. In another study, flood spread maps were created using HEC-RAS and GIS in semi-arid regions of Iran (Salajegheh et al., 2009). It has been seen that the studies in the literature have been conducted with similar approaches and methods. 
Spatial mapping in flood risk management can be done very quickly and practically with HEC-RAS and GIS software.

In the study, ArcGIS 9.3 GIS software and its extensions ArcHydro and Hec-GeoRAS 4.1 have been used for hydraulic modeling. HEC-RAS 4.1 hydraulic modeling software was used to calculate the flow geometry and flow data required for modeling.

\section{Study Area}

In this study, flood modeling was conducted in Porsuk Basin, which is located in the Eskişehir province. Porsuk Basin is a sub-basin of Sakarya Basin and has an area of $11,113.66 \mathrm{~km}^{2}$ in northwestern Anatolia. The basin lies between $29^{\circ} 38^{\prime}$ $31^{\circ} 59^{\prime}$ east longitudes and $38^{\circ} 44^{\prime}-39^{\circ} 99^{\prime}$ north latitudes. The basin is $202 \mathrm{~km}$ in east-west direction and $135 \mathrm{~km}$ in north-south direction (Figure 1). More than $60 \%$ of the basin is mountainous. The surface waters of the Porsuk Basin are collected by the Porsuk River and after reaching $436 \mathrm{~km}$ in the basin, it flows into the Sakarya River at a height of $660 \mathrm{~m}$. The long-term average annual rainfall of the Porsuk Basin is $445.1 \mathrm{~mm}$ (Bakış et al., 2008).
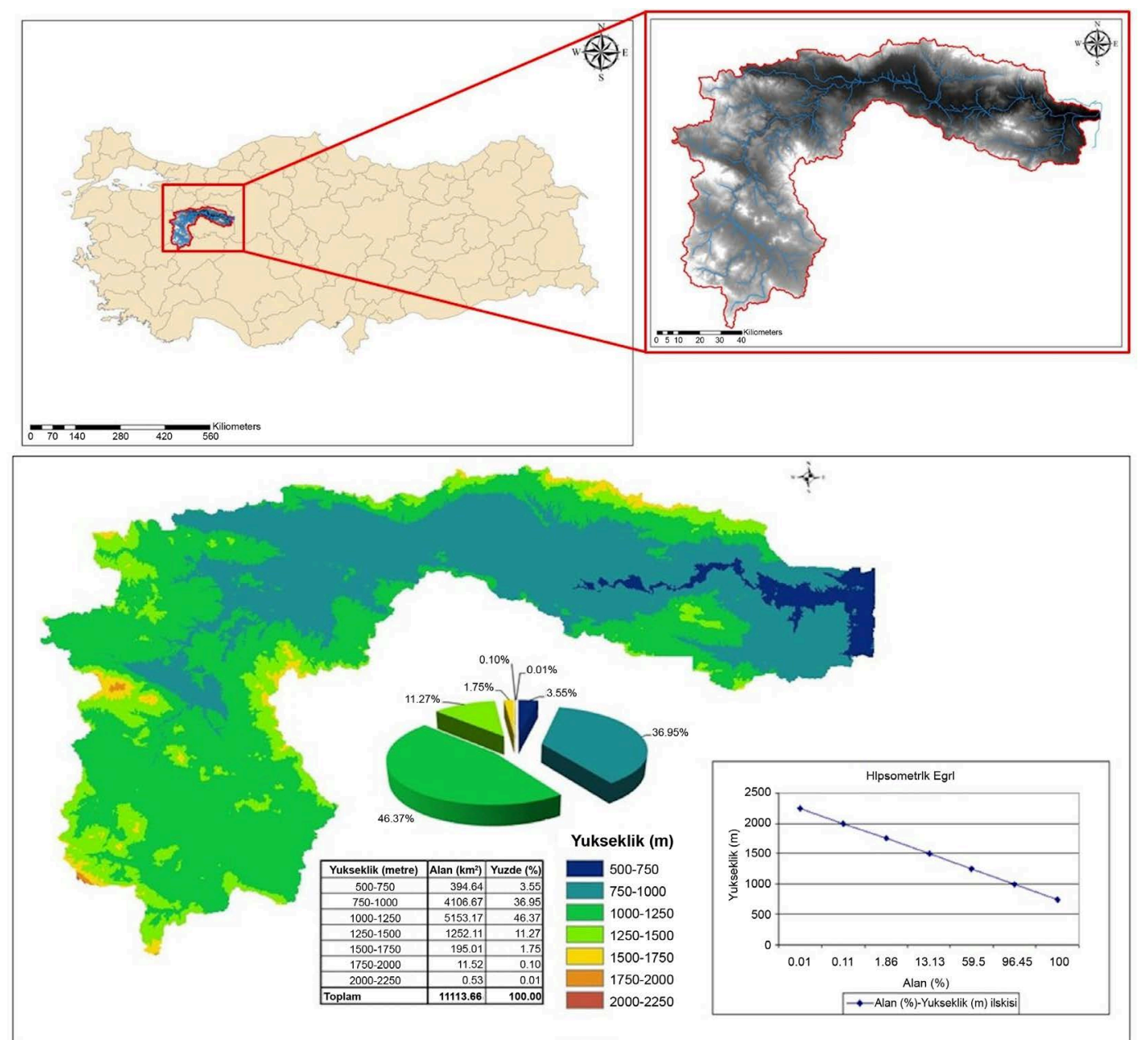

Figure 1. Location of Porsuk basin in Turkey, topographic maps and hypsometric curve of the basin. 


\section{Topographic Properties of the Study Area}

Using the numerical elevation model of Porsuk Basin, topographic features of the basin such as slope, aspect and shaded relief map of the basin were extracted. Each set of data represents important information in watershed planning. The spatial characteristics of the basin are classified and given in Figures 2(a)-(c).

The basin generally has a slope of less than 15 degrees. The slope of an area encompassing approximately $160.33 \mathrm{~km}^{2}$, which is $1.44 \%$ of the Porsuk Basin, has a topography above $30^{\circ}$ degrees (Figure $2(\mathrm{a})$ ). The aspect analysis is the horizontal angle of the surface with the north and approximately $3790.96 \mathrm{~km}^{2}$ of the research area consists of slopes facing south, southeast and southwest (Figure 2(b)). From the shaded relief map given in Figure 2(c), it is generally possible to see the structure and flat areas of the basin more clearly.

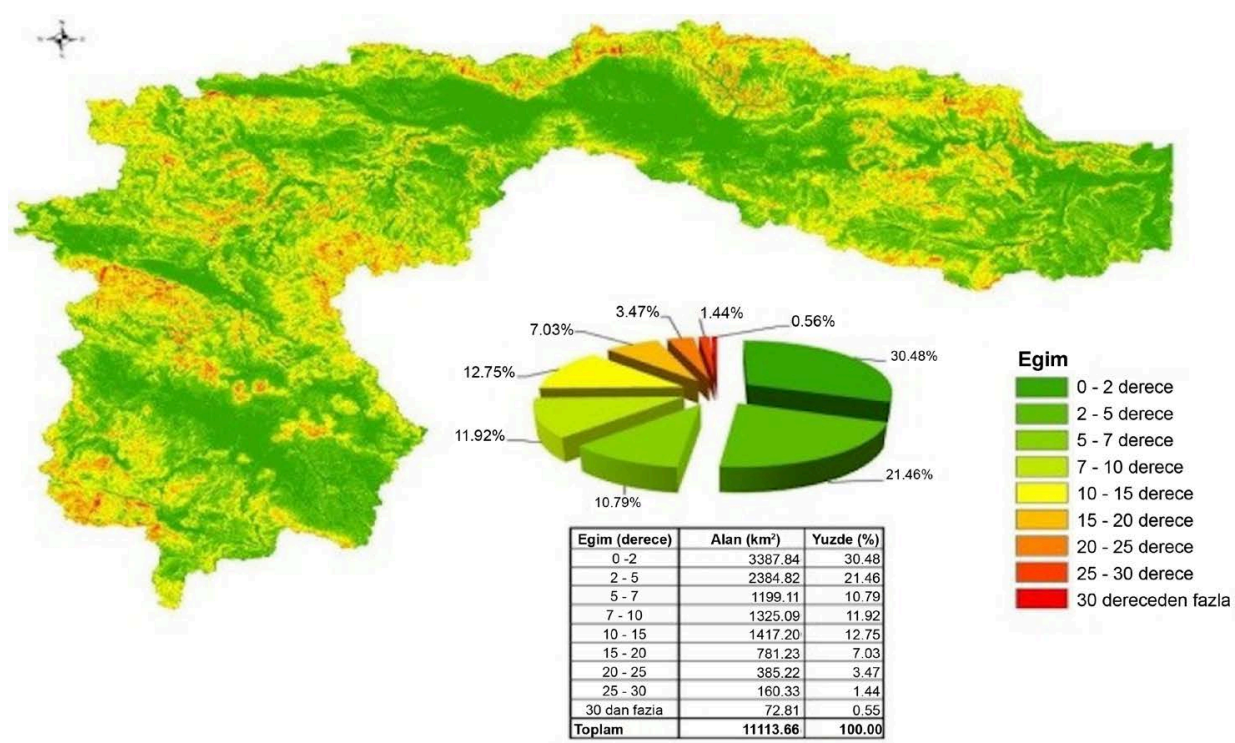

(a)

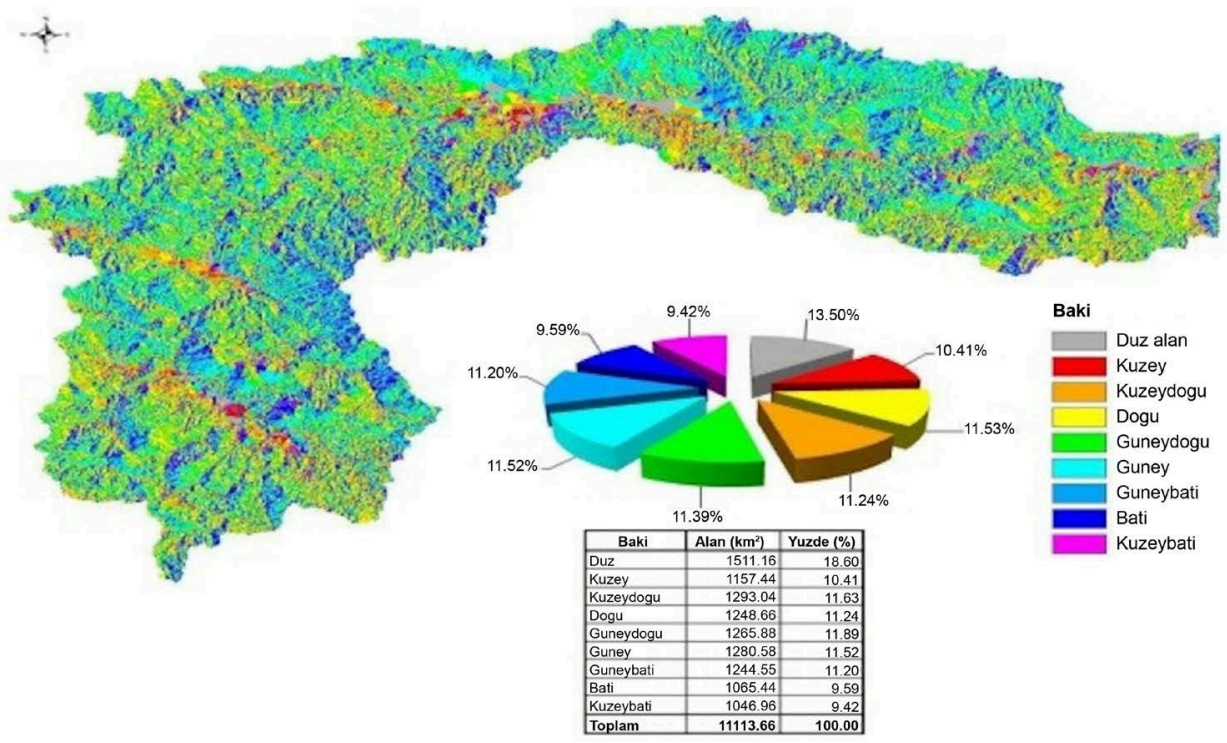

(b) 


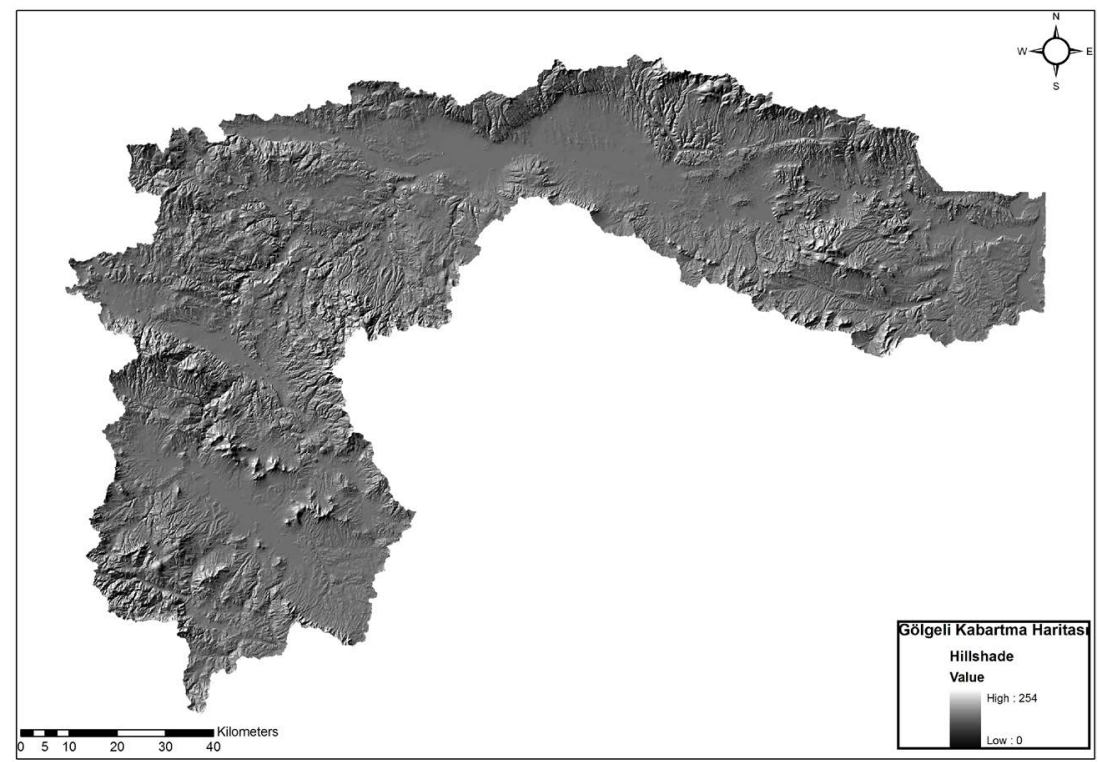

(c)

Figure 2. Topographic properties of Porsuk basin. (a) Slope Map; (b) Aspect Map; (c) Shaded Relief Map.

\section{Modeling and Mapping of Flood}

\subsection{Creating Spatial or Geographic Data}

Spatial data generated for flood mapping are the data of river beds for hydraulic modeling. These data generally consist of the establishment of connection of river systems, bed cross sections, identification of connection points, data of hydraulic structures and cross-section interpolations (Akar \& Maktav, 2008). The spatial data used in this study are from streams, river shores, flow paths and cross sections. These data are from $3.66 \mathrm{~km}^{2}$ of the Porsuk basin. Triangulated Irregular Network (TIN) model, which is produced from 1/25,000 digital topographic maps, was used as base data for the creation of spatial data. After the production of TIN, digitization of the geometric data in the area to be modeled and data entry operations were performed (Figure 3).

TIN model was used to digitize the data. Some of the features that are taken into consideration when digitizing and entering spatial or geographical data are as follows:

- Streams, stream shores and flow paths have been digitized in the direction of flow.

- The flow paths are defined (right, left and center).

- The bearing cross-sections have been digitized from the left bank to the right bank in the direction of stream flow.

- The cross-section lines intersected the river and flow paths only once and the two lines were not intersected.

\subsection{Creating a Flood Model}

HEC-RAS is a software model which models one-dimensional, regular and irre- 
gular currents (Merwade, 2016). In order to do modeling, it is necessary to enter the geometric data and the current data in the river bed (Özdemir, 2007). The geometric data of the study area were produced in HEC GeoRAS and other data were also completed in this section. The data were then transferred to the HEC-RAS software. After the completion of the geometric data input, the current data of the stream in the area where the modeling will be made, was entered. Flow data for flood repetition frequencies were accepted as Steady Flow data. Since the slope value of the study area is not too high, regular flow calculation was selected as subcritical. Then, 50, 100, 1000-year models were produced (Figure 4). In this study, 64-year flow data were used for the Flow Observation Station (FOS) data in the Yeniçiftlik River Basin. Thus, the year of 50, 100 and 1000 repetition frequencies of the maximum flood flow rates of the basin were calculated using Log Pearson Type III probability distribution function. Log Pearson Type III distribution function, which is a statistical technique applied to annual maximum flow data, is used to estimate flood frequencies at different intervals on rivers.

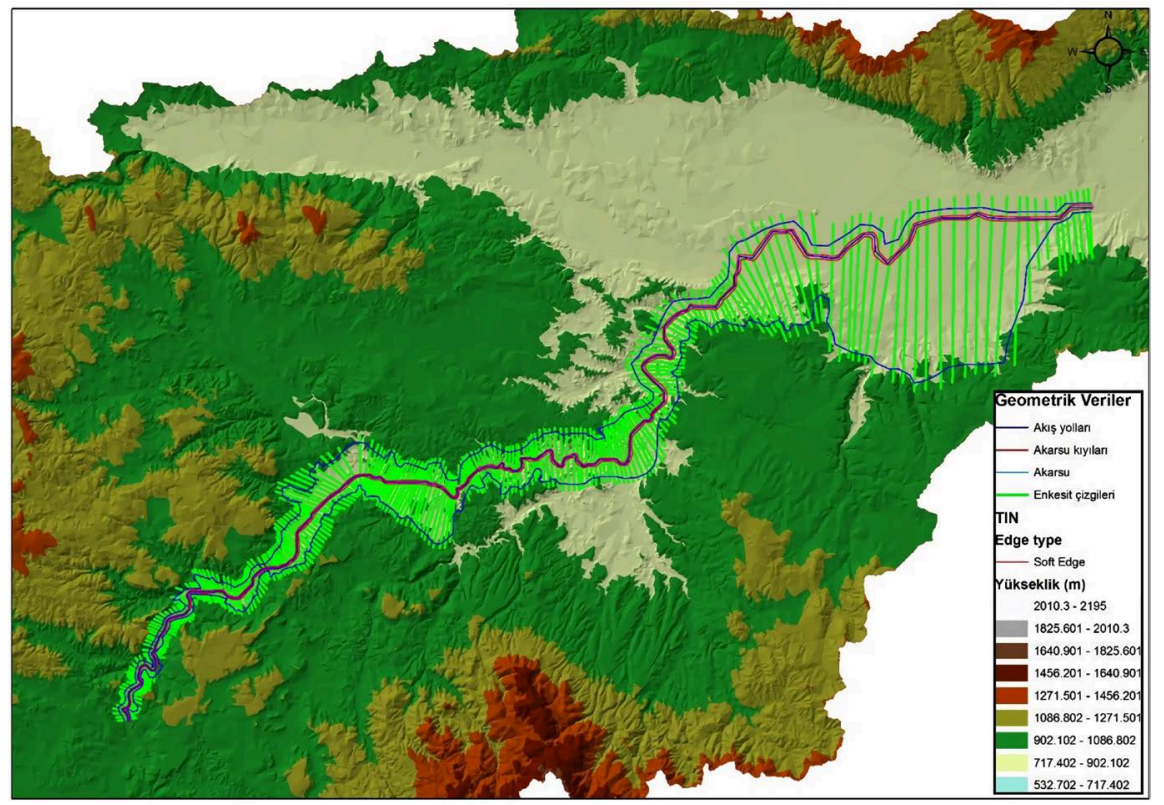

Figure 3. Geometric data used in flood mapping.

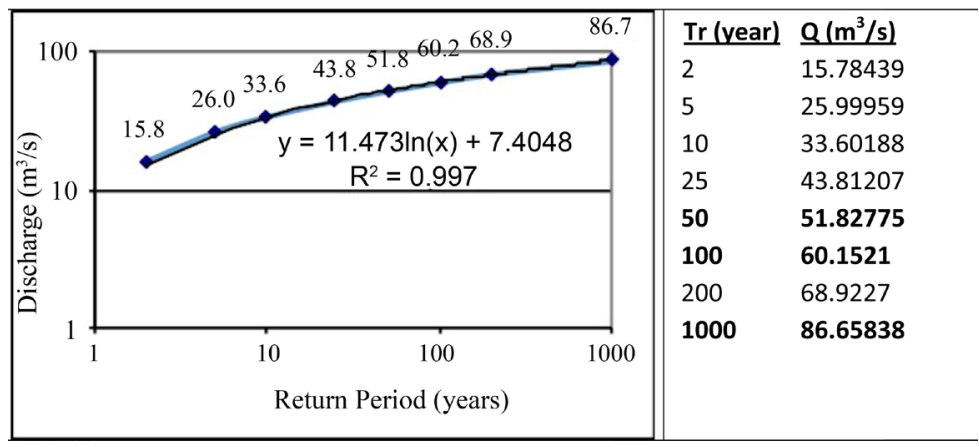

Figure 4. Flood rates. 
According to the determined flood flow rates, the data were analyzed at HEC GeoRAS and flood maps of 50,100 and 1000 years were created. These maps were also transferred into the Google Earth environment for a more detailed impression of Eskişehir province (Figure 5).

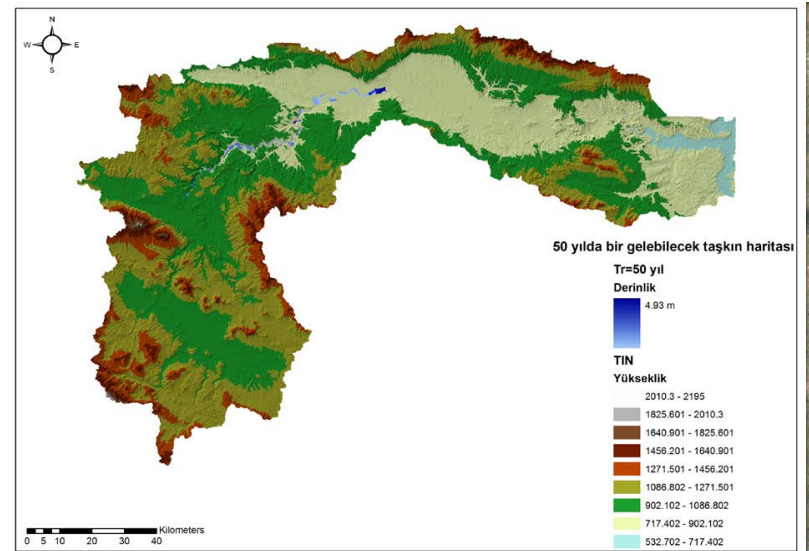

(a)

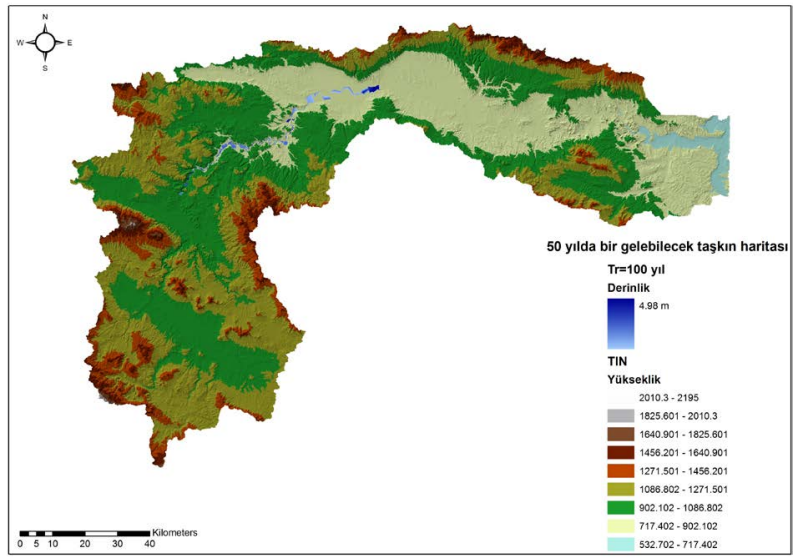

(c)

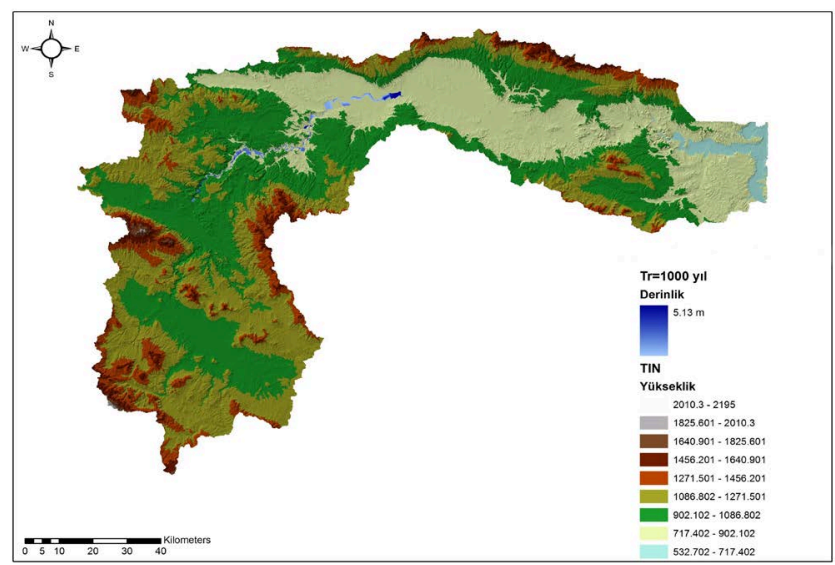

(e)

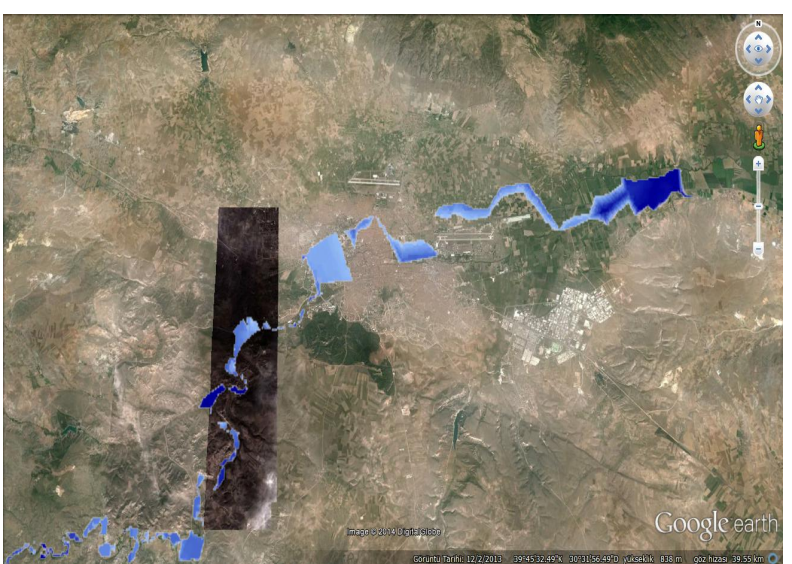

(b)

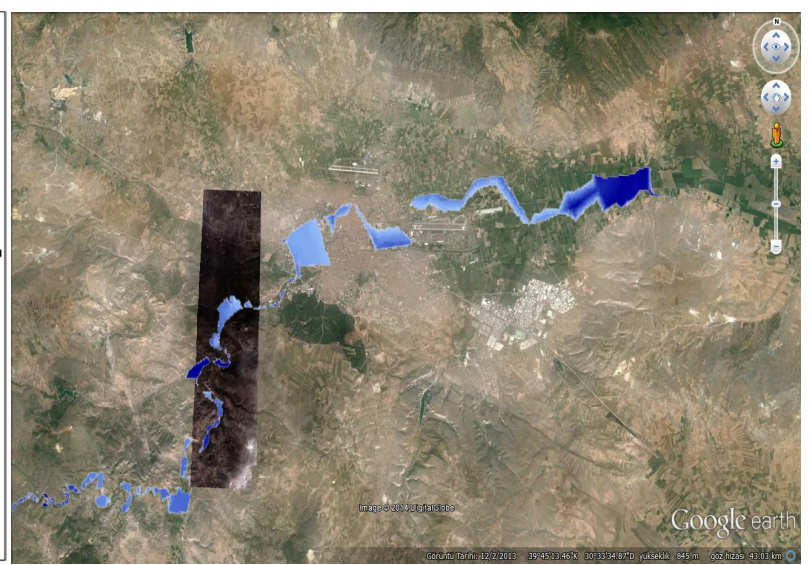

(d)

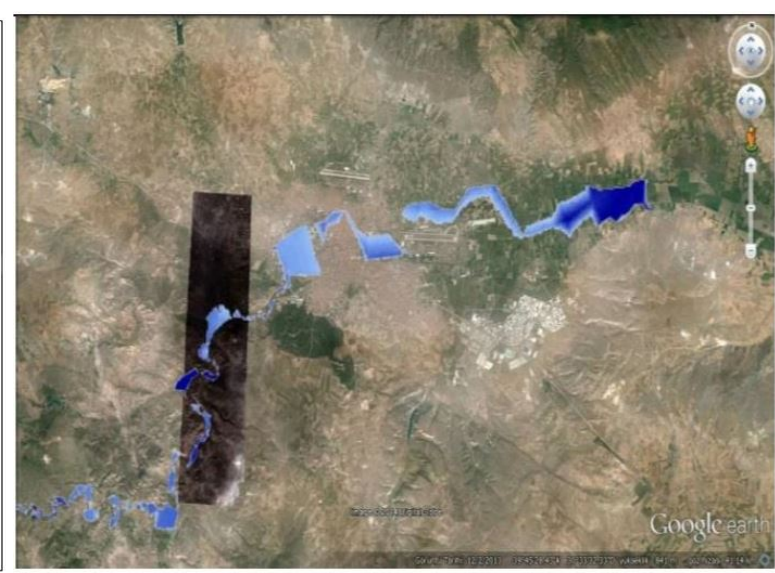

(f)

Figure 5. Porsuk basin flood maps. (a) Flood over 50 years period; (b) Flood in Google Earth for 50 years period; (c) Flood over 100 years period; (d) Flood in Google Earth for 100 years period; (e) Flood over 1000 years period; (f) Flood in Google Earth for 1000 years period. 


\section{Conclusion}

In this study, $361.6 \mathrm{~km}^{2}$ of the Porsuk basin, which also encompasses the province of Eskişehir, was investigated using GIS. In the study area, Porsuk dam was built for flood prevention after past flood events. However, this part of the basin has the potential for flooding due to sudden and continuous rains, as well as due to potential scenarios such as the collapse of the dam. Possible floods that may occur can severely affect settlement areas, industrial zones and fertile agricultural lands. In the hydrological and hydraulic modeling performed for flood mapping studies, flood rates the year of 50, 100 and 1000 were calculated using maximum flood flow rates of 64 years and possible flood maps were made by hydraulic modeling according to the obtained values. TIN model was used for the geometric data produced in the hydraulic model application and the stream center line, flow paths and cross sections were used; and then they were digitized via TIN model.

In this study, hydrological and hydraulic modeling is applied to determine the flood area and depth. As a result of the study, more detailed images were obtained by transferring the flood maps into Google Earth environment. As an outcome of this study, the regions of Eskişehir province that are under risk when exposed to such flood flow rates have been revealed.

During the flood periods of 50, 100 and 1000 years, the most affected districts of Eskişehir were Sümer and Ertuğrulgazi. In addition, some of the neighborhoods of Vişnelik and Şeker have also been affected by these floods. The reason for these neighborhoods to be affected more frequently has been found to be that they are built on the plain area where the Porsuk Stream passes.

\section{Conflicts of Interest}

The authors declare no conflicts of interest regarding the publication of this paper.

\section{References}

Akar, İ., \& Maktav, D. (2008). Taşkın Araştırmalarında Çok Kriterli Karar Verme Analizi Ve Hidrolojik Modellemelerin Uzaktan Algılama Ve CBS Entegrasyonu İle Karşılaştırılması, 2. Uzaktan Algılama ve CBS Sempozyumu, Kayseri, Türkiye.

Bakış, R., Altan, M., Gümüşlüoğlu, E., Tuncan, A., Ayday, C., Önsoy, H., \& Olgun, K. (2008). Porsuk Havzası Su Potansiyelinin Hidroelektrik Enerji Üretimi Yönünden İncelenmesi. Eskişehir Osmangazi Üniversitesi Mühendislik ve Mimarlık Fakültesi Dergisi, 21, 125-162.

Durdu, Ö. F. (2003). Robust Control of Irrigation Canals. Ph.D. Dissertation, Fort Collins, CO: Colorado State University, Civil Engineering Department.

HEC (2009). HEC-GeoRAS GIS Tools for Support of HEC-RAS using ArcGIS. U. S. Army Corps of Engineers, Institute for Water Resources, User's Manual 4.2.

HEC (2010). HEC-RAS River Analysis System. U. S. Army Corps of Engineers, Instute for Water Resources, Hydraulics Reference Manual 4.1.

Kılıçeri, Ü., Değirmencioğlu, N., \& Yayvan, M. (2000). Meteorolojik Kaynaklı Doğal Afetler Alt Komisyonu Raporu. Ankara, $28 \mathrm{~s}$. 
Merwade, V. (2016). Tutorial on Using HEC-GeoRASwithArcGIS 10.x and HEC-RAS Modelling.

https://web.ics.purdue.edu/ vmerwade/education/georastutorial.pdf

Özcan, O. (2008). Sakarya Nehri Alt Havzası'nın Taşkın Riski Analizinin Uzaktan Algılama ve CBS ile Belirlenmesi. İstanbul: İstanbul Teknik Üniversitesi.

Özcan, O., Musaoğlu, N., \& Şeker, D. Z. (2009). Taşkın Alanlarının CBS ve UA Yardımıyla Belirlenmesi ve Risk Yönetimi; Sakarya Havzası Örneği. TMMOB Harita ve Kadastro Mühendisleri Odası 12. Ankara: Türkiye Harita Bilimsel ve Teknik Kurultayı.

Özdemir, H. (2007). Havran Çayı Havzasının (Balıkesir) CBS ve Uzaktan Algılama Yöntemleriyle Taşkın ve Heyelan Risk Analizi. İstanbul: Basılmamış Doktora Tezi, İ.Ü. Sosyal Bilimler Enstitüsü, Coğrafya Anabilim Dalı.

Salajegheh, A., Bakhshaei, M., Chavoshi, S., Keshtkar, A. R., \& Hajivar, M. N. (2009). Floodplain Mapping Using HEC-RAS and GIS in Semi-Arid Regions of Iran. Desert, 14, 83-93.

Silva, F. V., Bonuma, N. B., \& Uda, P. K. (2014). Flood Mapping in Urban Area Using HEC-RAS Model Supported by GIS. Sao Paulo, Brazil: 6th International Conference on Flood Management.

Singh, V. P. (1996). Hydrologic Modelling with GIS. In V. P. Singh, \& M. Fiorentino (Eds.), Geographical Information Systems in Hydrology. Water Science and Technology Library (Vol. 26, pp. 1-13). Dordrecht: Kluwer Academic Publishers. https://doi.org/10.1007/978-94-015-8745-7_1

Uşkay, S., \& Aksu, S. (2002). Ülkemizde Taşkımlar, Nedenleri, Zararları ve Alınması Gereken Önlemler. Türkiye Mühendislik Haberleri, Sayı 420, 421, 422. 